\title{
HISTORY AND CULTURE: LEGITIMATION AND RESISTANCE IN CLASS SOCIETIES
}

The fifth annual conference of the Mid-Atlantic Radical Historians' Organization (MARHO) was held at Columbia University in New York City on April 16-17, 1977. The two day conference was attended by almost six hundred persons including teachers, students, and political activists. MARHO was founded in 1973 to provide a forum for the discussion of new perspectives on the study and teaching of history. It grew out of a shared concern among younger scholars, teachers and students to counter the narrow boundaries of professional history, the separation of the academy from social and political concerns and the growing divorce between teaching and research.

MARHO has three principal activities: forums, conferences, and the publication of the Radical History Review. Forums on a variety of historical subjects, on teaching, and on the current crisis in education are held regularly in New York, Boston, and Providence. Every spring MARHO sponsors a conference in New York City. MARHO also publishes the Radical History Review, a Marxist historical quarterly which has become the voice of the younger generation of radical historians in the United States. The fall 1976 issue contained an interview with E.P. Thompson, a symposium on Genovese's Roll, Jordan, Roll and an article on the Communist Party in Harlem. The winter issue contains articles, book reviews, and interviews dealing with pre-capitalist economic formations. A special spring issue will be devoted to the Great Depression. The Review is edited collectively by groups in New York, Boston, Providence, Baltimore, and Philadelphia.

This year's conference, entitled "History and Culture: Legitimation and Resistance in Class Societies," was structured around the theme of the historical role played by cultural expression and jnstitutions in the drive for capitalist hegemony and in the efforts of the working class to create oppositional cultures under capitalism. In this sense the conference attempted to define culture in a decidedly political way, seeing it as both an instrument of capitalist control and a weapon of working class opposition. This conception, while laudable as an overarching conference theme, never quite emerged in the majority of the panels, which were presented. There seemed to be two basic and counterpoised approaches taken in the papers with respect to the role of cultural forms and expression under capitalism: a sense of the near total bourgeois cultural hegemony over the working class; and the obverse, a celebration of all forms of working class cultural expression as inherently oppositional and even revolutionary. This is not surprising since these two approaches closely parallel the major ideological split in the writing of working class history between what can be called the "celebrationists" (Herbert Gutman being the most obvious example) and the "defeatists" (e.g., Eugene Genovese's work on the hegemony of Southern planters and his general emphasis on the dark and destructive impulses in the human psyche).

The necessity of merging these two tendencies in the writing of working class history was suggested forcefully by Stuart Hall in his keynote address to the conference participants. Arguing that "history from below" was a crucial and necessary first step, Hall urged the audience to go beyond "history from below" to a more comprehensive and dialectical "history of the whole." Hall argued against a simple celebration of working class life, urging intellectuals to take a fully critical role as leaders in and interpreters of working class activity and experience. Hall's comments received critical praise from Herbert Gutman and Paul Buhle, although both seemed to miss Hall's larger point about the vital necessity of developing a critical Marxist theory to inform the writing 
of working class history.

The afternoon session was devoted to four panels on the organization of dominant, bourgeois culture, including sessions on bourgeois ideological self-legitimation, civic uplift and social control, the extensions of scientific management techniques into social and cultural life and the creation of mass culture. Papers by Richard Andrews and Peter Linebaugh on bourgeois ideology during the French Revolution were particularly insightful, if somewhat abstruse in their presentation. The panel on civic uplift presented three interesting studies of the ways in which an ascendent bourgeoisie in the late 19th century employed cultural and social mechanisms as instruments of control over the working class: the youth movement in Britain; popular education in Spain; and drama and the theater in the U.S. The panel on mass culture was by far the most heavily attended and the most disappointing. The papers on mental health, television and the news media were generally rambling and unsystematic in their presentation, lacking the necessary theoretical framework that their subjects demanded.

The morning session of the second day was organized around the notion of the formation of working class oppositional cultures. The panel on workers' control and opposition to Taylorism generated a particularly lively debate over the issue of workers' control and its political significance for the development of the working class movement in America. The writings of David Montgomery and others were subjected to sharp scrutiny in a paper presented by Jon Amsden on scientific management and working class militancy. Arguing that the imposition of Taylorist practices was neither wide-spread nor particularly central to the demands put forward by U.S. workers on strike, Amsden challenged the validity of Montgomery's theory of workers' control. The second paper, presented by Bryan Palmer, was an elaboration on the importance of workers' control issues in the history of the Canadian working class movement and as such sharply diverged from Amsden's paper. The discussion which followed focused largely on the broader theoretical questions raised by the notion of "workers' control" for the development of a political instrument of working class power.

Other panels at the morning session of the second day included capitalism and the family (Eli Zaretsky on sex and the family, and Dierdre English on the professionalization of housework and child care), ethnic culture and class consciousness (Sirkka Lee on radical Finns, Joe Stipanovich on south Slav socialists, and Charles Leinenweber on early organization of the actor's union), American music (Lipsitz and Czitrom on the dialectics of music, Angeliki Keil on the polka, and Howard Johnson on jazz), and film and history (Al Auster on Hollywood, Lenny Quart on Frank Capra and the Popular Front, and Martin Jackson on historical uses of film).

The final session of the conference, entitled "Cultural Politics," was an effort to show the ways in which cultural and political questions had been addressed by left intellectuals both in the past and the present. The first panel on intellectuals and cultural organizing included insightful presentations by Molly Nolan on the German SPD's role in working class education and culture, Jimmy Fisher on the French C.P. and the Popular Front, and George Bernstein on Gramsci's theories of revolutionary education. The second panel included presentations by two contemporary novelists, Myra Page and Katya Gulden, on the political and cultural implications of writing novels. The third panel, on cultural imperialism, was the only one at the conference to address the third world. This was one of the most glaring problems in the organization of the conference as a 
whole and suggests the rather marked Euro-American bias in MARHO as an organization. In any case papers by Juan Corradi on cultural dependency in Latin America and Liz Dore on Peru were presented. Corradi's paper was especially noteworthy in that it attempted a broad theoretical construct for considering the role of culture in contemporary political struggles in Latin America. His attack on dependency theory was particularly insightful.

The final panel in the afternoon session was given over to representatives of three on-going and one proposed left journals, Science and Society, Radical America, In These Times, and Marxist Perspectives. The purpose of the panel was to allow each journal representative to present an editorial statement and some reflections on the problems of putting out a left publication in contemporary America. The presentations were largely uninspired however, and several were decidedly disingenuous, particularly James Weinstein for In These Times and Jacques Marchand for Marxist Perspectives. The discussion which followed was sharp if not always enlightening, with particularly pointed criticisms made from the floor of these latter two journals. The moral of this panel seemed to be that, despite professions to the contrary, American left intellectuals can be as self-serving and disunited as their supposedly more sectarian European counterparts.

Overall the conference was a success, despite the uneven quality of the papers and the general absence of a theoretical framework in many of the panels. It should be noted that the MARHO conference committee was sharply criticized by several feminist academics for what they perceived as the systematic exclusion of feminist history from the sessions. While more thought might well have been given to additional ways in which to integrate women's history, it should be said that the conference committee determined at the outset to resist the strongly separatist tendencies in much of feminist historical writing in favor of an overall conceptual approach to questions of culture and history. While the committee certainly erred in not involving women historians on several key panels, including most notably the keynote session, the decision not to put women's history "off in a separate room" seems to have been correct in retrospect.

Abstracts of the papers presented at the conference, together with a complete list of those who presented or commented on papers may be obtained by writing to MARHO, Box 946, New York, NY 10025. 